\title{
Histological and Histochemical Study on Stomach of Salamandra infraimmaculata (Amphibia: Urodela)
}

\author{
Esra Akat \\ Ege University, Science Faculty, Biology Department, Zoology Section 35100 Bornova-Izmir, Turkey \\ Tel: +902323112404; Fax: +902323881036 \\ esra.akat@ege.edu.tr \\ Received: 26 May 2017 \\ Accepted: 14 February 2018 \\ DOI: $10.18466 /$ cbayarfbe. 407997
}

\begin{abstract}
In the current study, we aimed to investigate the histological and histochemical characteristics of stomach of Salamandra infraimmaculata. The stomach of $S$. infraimmaculata was composed of four distinct layers; mucosa, submucosa, muscularis externa and serosa. The inner surface of gastric mucosa was lined by surface mucous cells which were simple columnar epithelium. Gastric glands were observed in mucosa. Mucous neck cells were located at the upper portion of glands, besides oxynticopeptic cells which were predominant at the gland body. The secretory components of mucous cells were neutral and acidic glycoproteins. The mucosa was separated from muscularis externa through submucosa which was formed by loose connective tissue. Muscularis externa consisted of a thick layer of smooth muscle. The muscularis externa was surrounded by the serosa which was the outermost layer of digestive tract.
\end{abstract}

Keywords - Amphibian, glycoproteins, mucous neck cell, oxynticopeptic cell, stomach, surface mucous cell

\section{Introduction}

Digestive tract is one of the most active and essential system due to digestion of food, absorption and waste removal [1,2]. The entire of gastrointestinal epithelium is coated with mucus, which protects surface of it. Mucus covers most surface of body such as digestive and respiratory systems, genital tract, the skin of amphibians and fish [3-6]. Mucus is a effective semipermeable barrier which provides the exchange of nutrients, water, gases, hormones and gametes while being impermeant to many pathogens [4]. The viscoelasticity of mucus is correlated with concentration of mucins. Mucins are high molecular weight glycoproteins [7]. Glycoproteins are proteins which carry covalently-bonded sugar units [8].

Amphibians are study model for many biological processes. Therefore research on them encompasses many field such as morphology, histology, embryology, ecology, endocrinology, genetic and public health [9-14].

The genus Salamandra is composed of 6 species and shows a wide geographical distribution. Salamandra infraimmaculata is a thick bodied, robust salamander with maximum total length of about $25--32 \mathrm{~cm}$. The females are usually larger than males and cloacal region is swollen in males. S. infraimmaculata is black salamander with big yellow dots over the whole body, except the belly. This is the largest fire salamander species which are active at twilight, spending most of the day under snags and stones. During rainy weather, salamanders leave their hiding places. The adults feed on insects, earthworms, slugs and snails $[15,16]$.

In the current study, we aimed to investigate the histological characterization and composition of the mucins in the gastric mucosa and discuss probable function of mucins in the stomach of $S$. infraimmaculata.

\section{Materials and Methods}

Two adult males/females of $S$. infraimmaculata were utilized in the current study. Salamanders were obtained from their natural habitat in Hatay/Turkey (36.492516 N, $36.203558 \mathrm{E}$ ), anaesthetized with ether, and euthanized by decapitation. Stomach samples were fixed in Bouin's fluid for $48 \mathrm{~h}$. Then tissue samples were dehydrated in ethanol, cleared in xylol and embedded in paraffin. Sections (5 $\mu \mathrm{m})$ were stain with Gill's hematoxylin-eosin (HE), Periodic acid-Schiff (PAS) and Alcian blue (AB). Sections were examined by Zeiss AxioScope A1 microscope attached to a digital camera (Axiocam Erc 5s). 


\section{Results and Discussion}

The present study has been focused on the histological and histochemical characterization of the stomach in $S$. infraimmaculata. The stomach was composed of four distinct layers as described for digestive tract of other vertebrates [17-19]; mucosa, submucosa, muscularis externa and serosa (Figure 1).

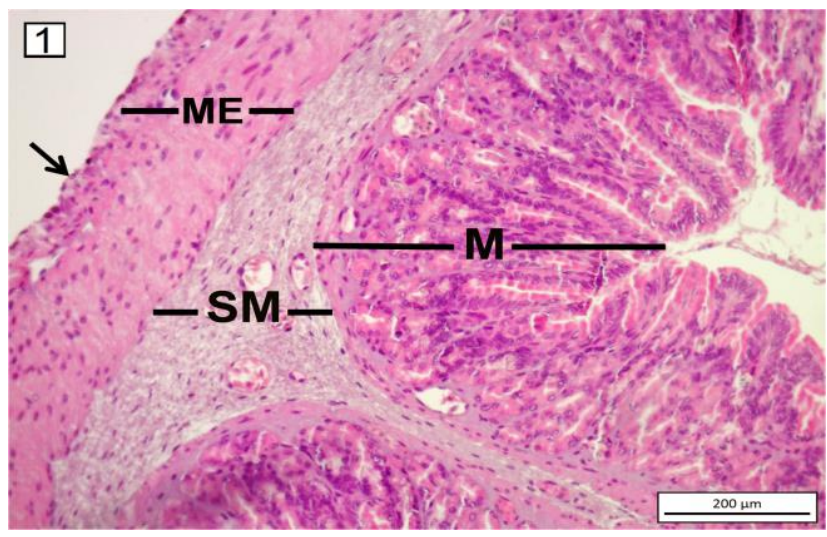

Figure 1. Light microscopic view of the stomach of $S$. infraimmaculata. The layers of stomach; mucosa (M), submucosa (SM), muscularis externa (ME), serosa (arrow). HE staining.

The mucosa was the innermost layer of the stomach. It was made up of three layers; epithelium, lamina propria and muscularis mucosa. The gastric mucosa showed numerous folds. It was made of the lining epithelium supported by loose connective tissue which was lamina propria. The inner surface of gastric mucosa was lined by surface mucous cells which were simple columnar epithelium as in other vertebrates [17,20,21]. Interestingly, for other anurans, the lining epithelium was constituted by ciliated cells as in the larval stage of Xenopus laevis [20] and in Rana temporaria [22].

Apical portion of the surface mucous cells was weak alcianophilic and exhibited strong staining after PAS (Figures 2, 3). These histochemical results indicated that the surface mucous cells were rich in neutral glycoproteins. Ferri et al. [23], who described epithelial cells of stomach of Rana aurora aurora produced neutral and acidic mucins. However, mucous cells of the stomach of Triturus carnifex [24], Rhinella icterica [25] mainly produced neutral glycoproteins. The mucus layer has important roles including the protection of underlying epithelium from mechanical and chemical stress, electrolyte absorption, increasing digestive efficiency and lubrication of tract [26-28]. Neutral glycoproteins have protective function against mechanical injuries, pathogens and pepsin [23].
Furthermore, neutral glycoproteins are poor in anions. This may prevent hydrogen ions and water molecules in the gastric juice being drawn into the protective mucus layer [29]. Alcian blue staining method indicated acidic glycoproteins that could be responsible for an increasing viscosity of the secretions [30]. Acidic glycoproteins were also reported to protect the intestinal epithelium against the degradative actions of glycosidases [27].

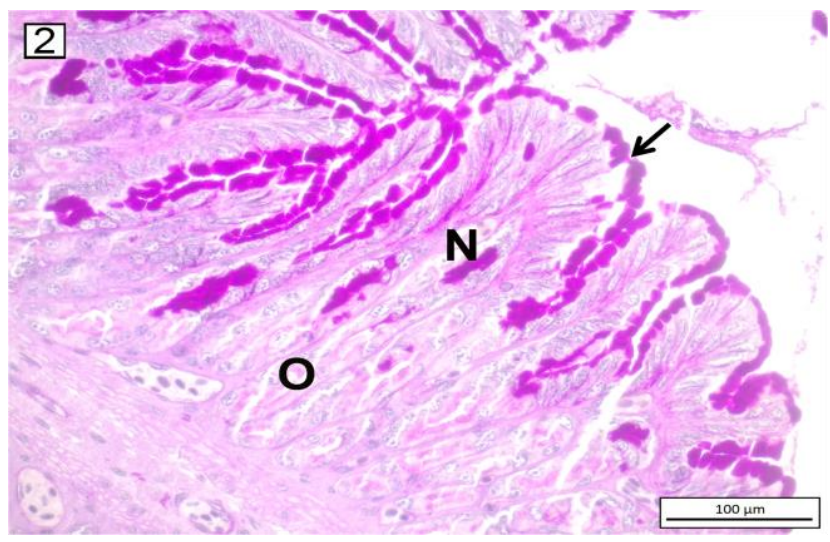

Figure 2. Gastric glands composed of mucous neck cells (N) at the upper portion of glands and oxynticopeptic cells (O) at the lower portion. Neutral glycoproteins were identified at the apical domain of surface mucous cells (arrow) and mucous neck cells (N), PAS method

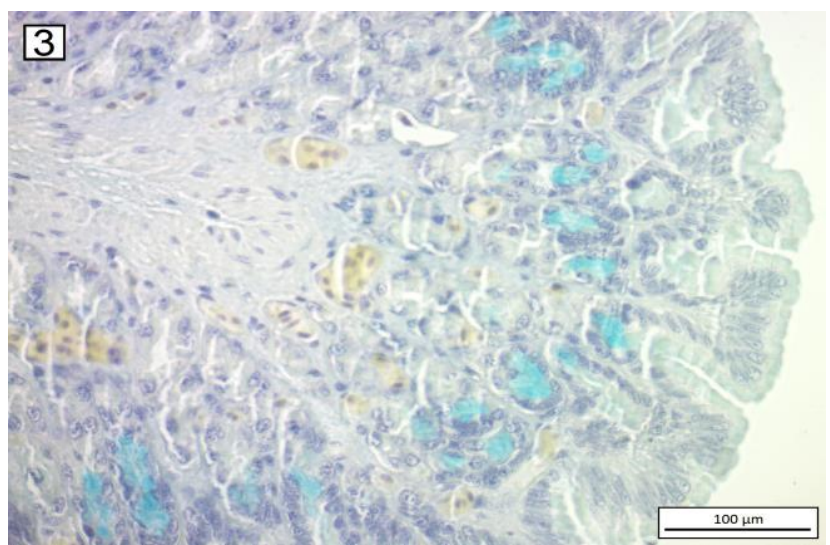

Figure 3. Gastric mucosa of $S$. infraimmaculata. Neck cells were stained with $\mathrm{AB}$ method.

Mucous neck cells were located at the upper portion of glands, besides oxynticopeptic cells which were predominant at the gland body (Figure 2). Scillitani et al. [21] reported that in the base region of the fundic glands of Natrix natrix, there were mainly oxynticopeptic cells. According to Suganuma et al. [31], amphibians were the first vertebrates to develop true mucous neck cells. The mucous neck cells were stained with AB and PAS. These histochemical results demonstrated that their contents included in both neutral and acidic glycoproteins. 
Oxynticopeptic cells were not stained with PAS and AB (Figures 2, 3). It was reported that oxynticopeptic cells produced and released both hydrochloric acid and pepsinogen in Bombina variegata [32], Bufo marinus [33], Triturus carnifex [34].

The mucosa was separated from submucosa through muscularis mucosa, which was a thin layer of smooth muscle that supports the mucosa and provides mucosa with the ability to move and fold. Crespo et al. [17] reported the absence of muscularis mucosa between the lamina propria of the mucosa and the submucosa in Dentex dentex. The submucosa was composed of loose connective tissue. Muscularis externa consisted of a thick layer of smooth muscle. The serosa was the outermost layer of digestive tract. It consisted of two layers, a thin layer of loose connective tissue and mesothelium. The connective tissue was surrounded by mesothelium which was simple squamous epithelium.

It can be concluded that the gastric wall of $S$. infraimmaculata was composed of four histologically distinct layers; mucosa, submucosa, muscularis externa and serosa as described for digestive tract of other vertebrates. The secretory components of mucous cells were neutral and acidic glycoproteins. Compared with the studies published to date, our results added information for characterization of stomach of S. infraimmaculata.

\section{Acknowledgements}

The current study was approved by the Animal Ethical Committee of Ege University, Faculty of Medicine (permit no: 2014-94) and Republic of Turkey Ministry of Forestry and Water Affairs (date: 20 February 2015, permit no: 43000).

\section{References}

1. Stevens, C.E.; Hume, I.D. Comparative physiology of the vertebrate digestive system. Cambridge University Press, Cambridge, 2004.

2. Junqueira, L.C.; Carneiro, J. (Çeviri: Y. Aytekin, S. Solakoğlu). Temel Histoloji. İstanbul: Nobel matbaacılık, 2006, pp 291-307.

3. Kunz, G.; Beil, D.; Deininger, H.; Wildt, L.; Leyendecker, G. The dynamics of rapid sperm transport through the female genital tract: evidence from vaginal sonography of uterine peristalsis and hysterosalpingoscintigraphy. Human Reproduction, 1996, 11(3), 627-632.

4. Cone, R.A. Barrier properties of mucus. Advanced Drug Delivery Reviews, 2009, 61(2), 75-85.

5. Akat, E.; Arıkan, H. Morphology and biometric study of skin of Hyla orientalis Bedriaga, 1890 (Anura, Hylidae). Russian Journal of Herpetology, 2013, 20(4), 253-258.

6. Akat, E.; Arıkan, H.; Göçmen, B. Histochemical and biometric study of the gastrointestinal system of Hyla orientalis (Bedriaga, 1890)
(Anura, Hylidae). European Journal of Histochemistry, 2014, 58(4), 291-295.

7. Lillehoj, E.P.; Kim, K.C. Airway mucus: its components and function. Archives of Pharmacal Research, 2002, 25(6), 770-780.

8. Cole, C.R.; Smith, C.A. Glycoprotein biochemistry (structure and function) - a vehicle for teaching many aspects of biochemistry and molecular biology. Biochemical Education, 1989, 17(4), 179-189.

9. Feder, M.E.; Burggren, W.W. Environmental physiology of the amphibians, University of Chicago Press, Chicago, 1992, pp 1-6.

10. Lutz, I., Blodt, S., Kloas, W. Regulation of estrogen receptors in primary cultured hepatocytes of the amphibian Xenopus laevis as estrogenic biomarker and its application in environmental monitoring. Comparative Biochemistry and Physiology C, 2005, 141, 384-392.

11. Hayes, T.B.; Case, P.; Chui, S.; Chung, D.; Haeffele C.; Haston, K.; Lee, M.; Mai, V.P.; Marjuoa, Y.; Parker, J.; Tsui M. Pesticide mixtures, endocrine disruption, and amphibian declines: are we underestimating the impact? Environmental Health Perspectives, $2006,114,40-50$.

12. Pittman, S.E.; Osbourn, M.S.; Semlitsch, R.D. Movement ecology of amphibians: a missing component for understanding population declines. Biological Conservation, 2014, 169, 44-53.

13. Amin, N.M.; Womble, M.; Ledon-Rettig, C.; Hull, M.; Dickinson, A; Nascone-Yoder, N. Budgett's frog (Lepidobatrachus laevis): A new amphibian embryo for developmental biology. Developmental Biology, 2015, 405, 291-303.

14. Langone, J.A.; Camargo, A.; de Sá, R.O. High genetic diversity but low population structure in the frog Pseudopaludicola falcipes (Hensel, 1867) (Amphibia, Anura) from the Pampas of South America. Molecular Phylogenetics and Evolution, 2016, 95, 137151.

15. Budak, A.; Göçmen, B. Herpetoloji (Ders Kitabı). İkinci baskı. Ege Üniversitesi Yayınları. Fen Fakültesi Yayın, (194), 2008.

16. AmphibiaWeb. Information on amphibian biology and conservation [web application]. AmphibiaWeb, Berkeley, CA, USA. Accessed on: 21.04.17. Available from: http://amphibiaweb.org/

17. Crespo, S.; Carrassón, M.; Dopazo, L. R.; Grau, A. A histological, histochemical and ultrastructural study of the digestive tract of Dentex dentex (Pisces, Sparidae). Histology and Histopathology, 2006, 21, 579-593.

18. Hariri, L.P.; Tumlinson, A.R.; Wade, N.H.; Besselsen, D.G.; Utzinger, U.; Gerner, E.W.; Barton, J.K. Ex vivo optical coherence tomography and laser-induced fluorescence spectroscopy imaging of murine gastrointestinal tract. Comparative Medicine, 2007, 57(2), 175-185.

19. Hamdi, H.; El-Ghareeb, A.W.; Zaher, M.; AbuAmod, F. Anatomical, histological and histochemical adaptations of the avian alimentary canal to their food habits: II-Elanus caeruleus. International Journal of Engineering Science, 2013, 4(10), 1355-1364.

20. Smith, D.M.; Grasty, R.C.; Theodosiou, N.A.; Tabin, C.J.; Nascone-Yoder, N.M. Evolutionary relationships between the amphibian, avian, and mammalian stomachs. Evolution \& Development, 2000, 2(6), 348-359. 
21. Scillitani, G.; Mentino, D.; Liquori, G.E.; Ferri, D. Histochemical characterization of the mucins of the alimentary tract of the grass snake, Natrix natrix (Colubridae). Tissue and Cell, 2012, 44(5), 288295.

22. Rovira, J.; Villaro, A.C.; Bodegas, M.E.; Valverde, E.; Sesma, P. Structural study of the frog Rana temporaria larval stomach. Tissue and Cell, 1993, 25(5), 695-707.

23. Ferri, D.; Liquori, G.E.; Natale, L.; Santarelli, G.; Scillitani, G. Mucin histochemistry of the digestive tract of the red-legged frog Rana aurora aurora. Acta Histochemica, 2001, 103(2), 225-237.

24. Liquori, G.E.; Mastrodonato, M.; Zizza, S.; Ferri, D. Glycoconjugate histochemistry of the digestive tract of Triturus carnifex (Amphibia, Caudata). Journal of Molecular Histology, 2007, 38(3), 191-199.

25. Machado-Santos, C.; Pelli-Martins, A.A.; Abidu-Figueiredo, M.; de Brito-Gitirana, L. Histochemical and immunohistochemical analysis of the stomach of Rhinella icterica (Anura, Bufonidae). Journal of Histology, 2014, Artical ID 872795, 1-8.

26. Allen A. Structure and function of gastrointestinal mucus. In Johnson L, editor. Physiology of the gastroenterology tract, 1 st edn. New York, NY: Raven Press, 1981, 617-639.

27. Neutra, M.; Forstner, J. Gastrointestinal mucus: synthesis, secretion, and function. In: Johnson L, editor. Physiology of the gastrointestinal tract, 2nd edn. New York, NY: Raven Press, 1987.

28. Gupta, B.L. The relationship of mucoid substances and ion and water transport, with new data on intestinal goblet cells and a model for gastric secretion. In Symposia of the Society for Experimental Biology, 1989, 43, 81 .

29. Leknes, I.L. Histochemical studies on mucin-rich cells in the digestive tract of a teleost, the Buenos Aires tetra (Hyphessobrycon anisitsi). Acta Histochemica, 2011; 113(3), 353-357.

30. Díaz, A.O.; García, A.M.; Goldemberg, A.L. Glycoconjugates in the mucosa of the digestive tract of Cynoscion guatucupa: a histochemical study. Acta Histochemica, 2008, 110(1), 76-85.

31. Suganuma, T.; Katsuyama, T.; Tsukahara, M.; Tatematsu, M.; Sakakura, Y.; Murata, F. Comparative histochemical study of alimentary tracts with special reference to the mucous neck cells of the stomach. Developmental Dynamics, 1981, 161(2), 219-238.

32. Bani, G.; Formigli, L.; Cecchi, R. Morphological observations on the glands of the oesophagus and stomach of adult Rana esculenta and Bombina variegata. Italian Journal of Anatomy and Embryology, 1992, 97(2), 75-87.

33. Ruiz, M.C.; Abad, M.J.; González, B.; Acosta, A., Michelangeli, F. Comparison of acid and pepsinogen secretion control by oxyntopeptic cell of amphibians. Acta Cientifica Venezolana, 1993, 44(2), 89-94.

34. Liquori, G.E.; Zizza, S.; Mastrodonato, M.; Scillitani, G.; Calamita, G.; Ferri, D. Pepsinogen and H, K-ATPase mediate acid secretion in gastric glands of Triturus carnifex (Amphibia, Caudata). Acta Histochemica, 2005, 107(2), 133-141. 